\title{
Efektivitas Kepatuhan Protokol Kesehatan Covid-19 Pada Pekerja Sektor Informal Di Kota Makassar
}

\section{Effectiveness of Compliance With Covid-19 Health Protocols In Informal Sector Workers In Makassar City}

\author{
Muh. Yusri Abadi ${ }^{1}$, Dian Saputra Marzuki ${ }^{1}$, Suci Rahmadani ${ }^{1}$, Muhammad \\ Al Fajrin ${ }^{1}$, Afiifah ${ }^{2}$, Arvina Pebrianti $\mathbf{H R}^{2}$ \\ ${ }^{1}$ Departemen Administrasi dan Kebijakan Kesehatan, FKM Unhas Makassar \\ ${ }^{2}$ Mahasiswa Program Sarjana Departemen Administrasi dan Kebijakan Kesehatan, \\ FKM Unhas Makassar \\ (Email: abadiyusri@gmail.com, diansaputramarzuki@gmail.com, \\ sachy.dani@gmail.com, fjr20fjr@gmail.com, afiifahfifaas@gmail.com, \\ arvinapebrianti14@gmail.com)
}

\begin{abstract}
ABSTRAK
Menghadapi adaptasi kebiasaan baru menuju masyarakat produktif dan aman terhadap COVID-19 Menteri Kesehatan menerbitkan Keputusan Menteri Kesehatan nomor HK.01.07/MENKES/382/2020 tentang Protokol Kesehatan. Target dalam penelitian ini tersedianya Kajian Efektivitas Kepatuhan Protokol Kesehatan COVID-19 pada pekerja sector Informal di Terminal Mallengkeri. Penelitian ini adalah metode kuantitatif dengan desain cross sectional. Penelitian dilaksanakan di Terminal Mallengkeri. Populasi dalam penelitian ini adalah seluruh supir Terminal Mallengkeri dengan jumlah sampel sebanyak 97 responden menggunakan Teknik accidental sampling. Hasil penelitian menunjukkan bahwa terdapat 88 responden $(90.7 \%)$ yang baik dan 9 responden $(9.3 \%)$ yang kurang baik dalam efektivitas kepatuhan protokol kesehatan COVID-19. Adapun hasil uji statistik menunjukkan bahwa pencapaian tujuan dan hasil $(p=0.004)$, kepuasan kelompok sasaran $(p=0.357)$, sistem pemeliharaan $(p=0.236)$, tindakan $(p=0.068)$, fasilitas $(p=0.288)$, dan motivasi $(p=0.744)$. Berdasarkan hasil penelitian, dapat disimpulkan bahwa hanya variabel pencapaian tujuan dan hasil yang memiliki hubungan signifikan dengan efektivitas kepatuhan protokol kesehatan COVID-19, sedangkan variabel-variabel lainnya tidak terdapat hubungan.
\end{abstract}

Kata kunci: Pekerja sektor informal, Pedoman kepatuhan, Covid-19.

\section{ABSTRACT}

Dealing with the new habit adaption towards a productive and safe society against COVID-19, the Ministry of Health issued a Minister for Health Decree number HK.01.07 / MENKES / 382/2020 concerning Health Protocols. This study looks for the availability of a Covid-19 Health Protocol Compliance Effectiveness Study for Informal sector workers at Mallengkeri Terminal. This research is a quantitative method with a crosssectional design. The research was examined at Mallengkeri Terminal. The population of the study consisted of Mallengkeri Terminal drivers with a total sample of 97 respondents using the accidental sampling technique. In the study, it was found that there were 88 respondents (90.7\%) who were good and 9 respondents (9.3\%) who were not good enough in the effectiveness of compliance with the COVID-19 health protocol. The statistical test results show that the achievement of goals and results $(p=0.004)$, target group satisfaction $(p=0.357)$, maintenance systems $(p=0.236)$, action $(p=0.068)$, facilities $(p=0.288)$, and motivation $(p=0.744)$. Based on the research results, it is concluded that only the achievement of goals and outcomes variables have a significant relationship with the effectiveness of compliance with the COVID-19 health protocol and the other variables have no correlation.

Keywords: Informal Sector worker, Guideline Adherence, Covid-19. 


\section{PENDAHULUAN}

Kasus pneumonia dilaporkan pertama kali pada Desember 2019 di Wuhan, Provinsi Hubei China, terdapat lima pasien yang dirawat dengan Acute Respiratory Distress Syndrome (ARDS) yang ternyata menunjukkan etiologi coronavirus baru (Ren et al., 2020). Virus SARS-CoV-2, Coronavirus termasuk ke dalam kelompok virus penyebab Severe Acute Respiratory Syndrome (SARS) dan Middle-East Respiratory Syndrome (MERS). Penyebaran Virus Corona (COVID-19) di seluruh dunia telah menyebabkan krisis kesehatan masyarakat yang luar biasa. Dilaporkan kasus kematian akibat COVID-19 cukup besar, sehingga wabah SARS-CoV-2 yang meluas dinyatakan sebagai Public Health Emergency of International Concern (PHEIC) (Hanggoro et al., 2020).

Akibat penyebaran COVID-19 yang sangat cepat menyebabkan Indonesia menempatkan posisi 9 se-Asia yang kasus COVID-19 pertama kali dikonfirmasi pada tanggal 2 Maret 2020, sehingga peningkatan mortalitas COVID-19 di Indonesia mencapai 8,9\% yang menunjukkan angka tertinggi di Asia Tenggara (Saputra and Salma, 2020). Akumulasi kasus perkembangan COVID-19 di Indonesia terkonfirmasi positif hingga 16 Mei 2021 terdapat 1.739.750 kasus (Kemenkes RI, 2021). Berdasarkan data SulSel Tanggap COVID-19 terdapat 61.714 kasus yang terkonfirmasi aktif di Provinsi Sulawesi Selatan. Sedangkan data Info Penanggulangan COVID-19 Kota Makasssar Kecamatan Tamalate termasuk ke dalam urutan ke 3 zona merah.

Sistem Monitoring Bersatu Lawan Covid (BLC) menunjukkan perubahan perilaku grafik tren kepatuhan protokol kesehatan yang diwakili oleh Juru bicara pemerintah COVID-19 bahwa menurunnya kepatuhan sejalan dengan meningkatnya penambahan kasus positif. Pada periode Oktober-Desember 2020, kepatuhan memakai masker rata-rata diatas $70 \%$, menjaga jarak dan menjauhi kerumunan diatas $60 \%$. Sedangkan pada Desember 2020, kepatuhan memakai masker 55\% (turun 28\%). Menjaga jarak dan menghindari kerumunan turun ke 39\% (turun 20\%) (Satuan Tugas Penanganan COVID-19,2020). Maka dari itu, tindakan protokol kesehatan yang ditetapkan oleh WHO dan Kementerian Kesehatan RI tidak akan berjalan sebelum masyarakat dibekali dengan pengetahuan, sikap dan keterampilan yang baik dalam pelaksanaannya (Utami, $d k k$.2020).

Dalam Menghadapi adaptasi kebiasaan baru (AKB) menuju masyarakat produktif dan aman terhadap COVID-19 Menteri Kesehatan menerbitkan Keputusan Menteri Kesehatan nomor HK.01.07/MENKES/382/2020 tentang Protokol Kesehatan bagi Masyarakat di Tempat dan Fasilitas Umum. Hanya saja, kenyataannya masih jauh dari harapan lantaran kesadaran masyarakat untuk mematuhi protokol kesehatan COVID-19 masih terbilang minim. Hal ini pun telah dibenarkan Jubir Pemerintah untuk COVID-19 
Muh. Yusri Abadi, Dian Saputra Marzuki, Suci Rahmadani, Muhammad Al Fajrin, Afiifah, Arvina Pebrianti HR. : Efektivitas Kepatuhan Protokol Kesehatan Covid-19 ...

yang menunjukkan kepatuhan masyarakat terhadap protokol kesehatan belum optimal (Kemenkes RI, 2020).

Sektor informal merupakan sektor usaha yang berskala kecil. Kebanyakan penduduk Indonesia bekerja pada sektor industri informal dimana merupakan tempat bekerja yang tidak tetap dengan pendapatan yang juga tidak tetap, tempat pekerjaan yang tidak tersedia keamanan kerjanya, serta unit usaha atau yang tidak berbadan hukum (Abadi et al., 2019). Supir yang merupakan pekerja informal ikut terkena dampak pandemi COVID-19 dikarenakan kebijakan pembatasan sosial serta lokasi kerja supir yaitu Terminal Mallengkeri juga dapat menjadi lokus penyebaran COVID-19 karena merupakan unit transportasi di Kecamatan Tamalate, dimana lokasi tersebut salah satu zona merah pesebaran COVID-19 yang terbanyak sekecamatan Kota Makassar.

Berdasarkan observasi dan wawancara awal yang dilakukan oleh peneliti pada 8 dari 10 orang di Terminal Mallengkeri diperoleh data bahwa terdapat 80\% responden mengetahui bahwa protokol kesehatan COVID-19 penting untuk diadakan di Terminal sebagai upaya pencegahan COVID-19 dan juga mengetahui dampak yang terjadi jika tidak mematuhi protokol kesehatan COVID-19, namun ternyata terdapat $40 \%$ yang tidak patuh dalam protokol kesehatan COVID-19 padahal terdapat 90\% responden yang menyatakan bahwa terdapat satuan tugas COVID-19 yang mengatur pendisiplinan protokol kesehatan COVID-19 di Terminal Mallengkeri.

Hal ini ditandai dengan pengakuan supir angkutan dan penumpang yang menyatakan bahwa mereka merasa tidak nyaman dan tidak memiliki persediaan protokol kesehatan, bahkan saat di terminal tidak menjaga jarak. Selain itu, berdasarkan yang telah peneliti amati saat ini masyarakat di Terminal Mallengkeri kurangnya fasilitas protokol pencegahan seperti tempat cuci tangan, poster ajakan pencegahan COVID-19, bahkan tanda untuk jaga jarak. Berdasarkan permasalahan diatas, peneliti tertarik untuk melakukan penelitian tentang Efektivitas Kepatuhan Protokol Kesehatan COVID-19 di Terminal Mallengkeri Kecamatan Tamalate Kota Makassar Tahun 2020.

\section{METODE}

Jenis penelitian ini adalah analitik observasional dengan desain cross sectional. Penelitian ini dilaksanakan di Terminal Mallengkeri, Kota Makassar pada tanggal 17-25 Mei 2021. Populasi dalam penelitian ini adalah seluruh supir angkutan di Terminal Mallengkeri dengan jumlah sampel sebanyak 97 responden dengan menggunakan Teknik accidental sampling dengan mendatangi Terminal setiap hari dikarenakan tidak 
menentunya penumpang akibat dampak pandemi menjadikan supir tetap di Terminal Mallengkeri setiap hari untuk mencari penumpang. Adapun instrumen pada penelitian ini adalah kuesioner, alat tulis, kamera handphone, dan komputer. Pengumpulan data dilakukan dengan Teknik pengumpulan data kuantitatif yaitu wawancara dengan mengajukan pertanyaan kepada responden menggunakan kuesioner yang telah di uji validitas dan juga realibitas yang terdiri dari dua jenis skala pengukuran data yaitu skala Likert dan Guttman, kemudian mengamati (observasi) kondisi responden serta lokasi penelitian dan melakukan dokumentasi. Sedangkan teknik analisis pada penelitian ini dengan menggunakan program SPSS dengan model analisis univariat dan bivariat dengan menggunakan uji Chi Square. Hasil dari penelitian ini akan disajikan dalam bentuk tabel dan narasi untuk interpretasi dan pembahasan hasil penelitian.

\section{HASIL}

Karakteristik umum responden merupakan ciri khas yang melekat pada diri responden. Karakteristik umum responden meliputi kelompok umur, jenis kelamin, dan pendidikan terakhir responden dapat dilihat pada tabel berikut.

Tabel 1. Distribusi Responden Berdasarkan Umur, Jenis Kelamin, dan Pendidikan Responden di Terminal Mallengkeri

\begin{tabular}{lcc}
\hline \multicolumn{1}{c}{ Karakteristik } & Frekuensi $(\mathbf{n}=\mathbf{9 7})$ & Persen $\mathbf{( \% )}$ \\
\hline Kelompok Umur & 14 & \\
< 21 tahun & 27 & 14.4 \\
21-30 tahun & 29 & 27.8 \\
31-40 tahun & 18 & 29.9 \\
41-50 tahun & 9 & 18.6 \\
> 50 tahun & & 9.3 \\
\hline Jenis Kelamin & 78 & 80.4 \\
Laki-laki & 19 & 19.6 \\
Perempuan & & \\
\hline Pendidikan Terakhir & 5 & 5.2 \\
Tidak Tamat SD & 14 & 14.4 \\
Tamat SD/Se-derajat & 29 & 29.9 \\
Tamat SMP/Se-derajat & 37 & 38.1 \\
Tamat SMA/Se-derajat & 12 & 12.4 \\
Tamat Perguruan Tinggi & $\mathbf{9 7}$ & $\mathbf{1 0 0 . 0}$ \\
\hline \multicolumn{2}{c}{ Total } &
\end{tabular}

Hasil analisis karakteristik responden pada Tabel 1 menunjukkan bahwa distribusi karakteristik responden berdasarkan kelompok umur terbanyak yaitu kelompok umur 31-40 tahun sebanyak 29 responden (29,9\%). Sedangkan distribusi karakteristik responden yang paling sedikit yaitu kelompok umur $<50$ tahun sebanyak 9 responden $(9,3 \%)$. 
Muh. Yusri Abadi, Dian Saputra Marzuki, Suci Rahmadani, Muhammad Al Fajrin, Afiifah, Arvina Pebrianti HR. : Efektivitas Kepatuhan Protokol Kesehatan Covid-19 ...

Distribusi karakteristik responden berdasarkan jenis kelamin menunjukkan bahwa sebanyak 78 responden $(80,4 \%)$ berjenis kelamin laki-laki dan perempuan sebanyak 19 responden $(19,6 \%)$. Sementara itu, frekuensi tertinggi berdasarkan tingkat pendidikan terakhir yang ditempuh responden di Terminal Mallengkeri yaitu tamat SMA/SMK/Sederajat sebanyak 37 responden $(38,1 \%)$ dan terendah yaitu tidak tamat SD sebanyak 5 responden $(5,2 \%)$.

Tabel 2. Distribusi Responden Berdasarkan Variabel Dependen (Efektivitas Kepatuhan Protokol Kesehatan COVID-19) dan Variabel Independen (Pencapaian Tujuan dan Hasil, Kepuasan Kelompok Sasaran, Sistem Pemeliharaan, Tindakan, Fasilitas, dan Motivasi) pada Pedagang di Pasar Lakessi Kota Parepare

\begin{tabular}{|c|c|c|}
\hline Variabel & Frekuensi $(\mathbf{n = 9 7})$ & Persentase $(\%)$ \\
\hline \multicolumn{3}{|c|}{ Efektivitas Kepatuhan } \\
\hline \multicolumn{3}{|c|}{ Protokol Kesehatan COVID-19 } \\
\hline Baik & 88 & 90.7 \\
\hline Kurang Baik & 9 & 9.3 \\
\hline \multicolumn{3}{|c|}{ Pencapaian Tujuan dan Hasil } \\
\hline Terlaksana & 55 & 56.7 \\
\hline Tidak Terlaksana & 42 & 43.3 \\
\hline \multicolumn{3}{|c|}{ Kepuasan Kelompok Sasaran } \\
\hline Puas & 43 & 44.3 \\
\hline Tidak Puas & 54 & 55.7 \\
\hline \multicolumn{3}{|l|}{ Sistem Pemeliharaan } \\
\hline Tersedia & 69 & 71.1 \\
\hline Tidak Tersedia & 28 & 28.9 \\
\hline \multicolumn{3}{|l|}{ Tindakan } \\
\hline Baik & 38 & 39.2 \\
\hline Tidak Baik & 59 & 60.8 \\
\hline \multicolumn{3}{|l|}{ Fasilitas } \\
\hline Tersedia & 12 & 12.4 \\
\hline Tidak Tersedia & 85 & 87.6 \\
\hline \multicolumn{3}{|l|}{ Motivasi } \\
\hline Tinggi & 94 & 96.9 \\
\hline Rendah & 3 & 3.1 \\
\hline Total & 97 & 100.0 \\
\hline
\end{tabular}

Berdasarkan Tabel 2, dapat diketahui bahwa dari total 97 responden, sebanyak 88 responden $(90,7 \%)$ yang baik dan sebanyak 9 responden $(9,3 \%)$ yang kurang baik dalam efektivitas kepatuhan protokol kesehatan COVID-19.

Pada variabel pencapaian tujuan dan hasil, dapat diketahui bahwa dari total 97 responden, sebanyak 55 responden $(56,7 \%)$ yang termasuk kategori terlaksana dan sebanyak 42 responden $(43,3 \%)$ yang termasuk kategori tidak terlaksana. Sedangkan pada variabel kepuasan kelompok sasaran, dapat diketahui sebanyak 43 responden $(44,3 \%)$ 
yang puas dan sebanyak 54 responden $(55,7 \%)$ yang tidak puas. Sedangkan, pada variabel sistem pemeliharaan sebanyak 69 responden $(71,1 \%)$ yang menyatakan tersedia, dan sebanyak 28 responden $(28,9 \%)$ yang yang menyatakan efektivitas kepatuhan protokol kesehatan COVID-19 tidak tersedia.

Adapun pada variabel tindakan, diketahui bahwa sebanyak 38 responden $(39,2 \%)$ yang memiliki tindakan yang baik dan kurang baik sebanyak 59 responden $(68,8 \%)$. Selanjutnya, pada variabel fasilitas, diketahui sebanyak 12 responden $(12,4 \%)$ yang menyatakan fasilitas tersedia dan sebanyak 85 responden $(87,6 \%)$ yang menyatakan fasilitas tidak tersedia. Dan pada variabel motivasi sebanyak 94 responden $(96,9 \%)$ yang memiliki motivasi tinggi dan sebanyak 3 responden $(3,1 \%)$ memiliki motivasi rendah dalam efektivitas kepatuhan protokol kesehatan COVID-19.

Tabel 3. Hubungan Pencapaian Tujuan dan Hasil, Kepuasan Kelompok Sasaran, Sistem Pemeliharaan, Tindakan, Fasilitas, dan Motivasi Terhadap Efektivitas Kepatuhan Protokol Kesehatan COVID-19 di Terminal Mallengkeri

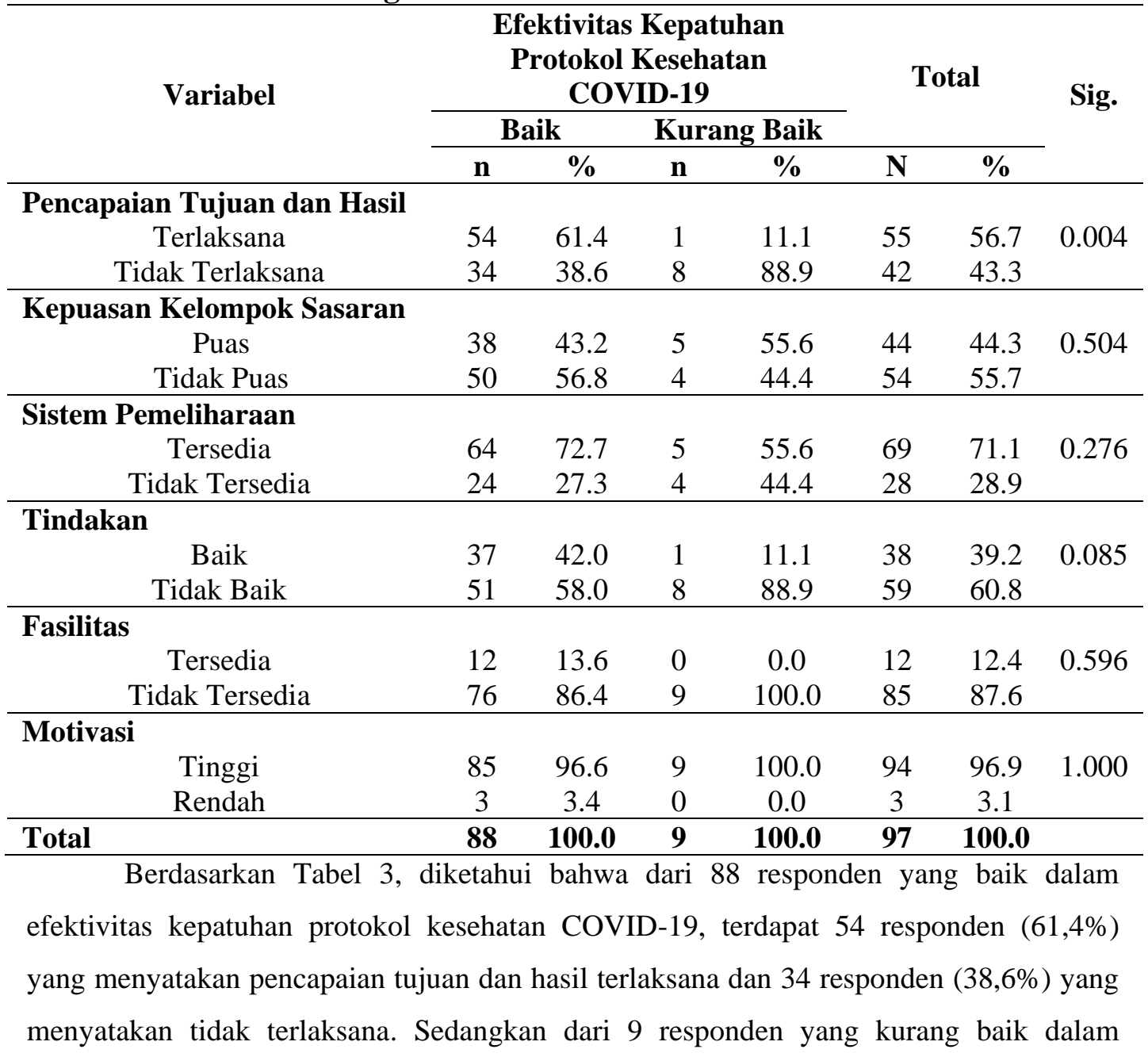


Muh. Yusri Abadi, Dian Saputra Marzuki, Suci Rahmadani, Muhammad Al Fajrin, Afiifah, Arvina Pebrianti HR. : Efektivitas Kepatuhan Protokol Kesehatan Covid-19 ...

efektivitas kepatuhan protokol kesehatan COVID-19, terdapat 8 responden (88.9\%) yang menyatakan pencapaian tujuan dan hasil tidak terlaksana, sementara yang menyatakan terlaksana dalam efektivitas kepatuhan protokol kesehatan COVID-19 sebanyak 1 responden $(11,1 \%)$.

Selanjutnya, terkait hubungan kepuasan kelompok sasaran terhadap efektivitas kepatuhan protokol kesehatan COVID-19, diperoleh data bahwa dari 88 responden yang baik dalam efektivitas kepatuhan protokol kesehatan COVID-19, terdapat 38 responden $(43,2 \%)$ yang puas dan 50 responden $(56,8 \%)$ yang tidak puas. Sedangkan dari 9 responden yang kurang baik dalam efektivitas kepatuhan protokol kesehatan COVID-19, terdapat 4 responden $(44,4 \%)$ yang tidak puas, sementara yang puas sebanyak 5 responden $(55,6 \%)$.

Sistem pemeliharan terhadap efektivitas kepatuhan protokol kesehatan COVID19, terdapat 64 responden $(72,7 \%)$ yang menyatakan tersedia dan 24 responden $(27,3 \%)$ yang menyatakan tidak tersedia dalam efektivitas kepatuhan protokol kesehatan COVID19. Sedangkan dari 9 responden yang kurang baik dalam efektivitas kepatuhan protokol kesehatan COVID-19, terdapat 4 responden $(44,4 \%)$ yang menyatakan tidak tersedia, sementara yang menyatakan tidak tersedia dalam efektivitas kepatuhan protokol kesehatan COVID-19 sebanyak 5 responden $(55,6 \%)$.

Hubungan tindakan terhadap efektivitas kepatuhan protokol kesehatan COVID19 terdapat 37 responden $(42,0 \%)$ yang memiliki tindakan yang baik dan 51 responden $(58,0 \%)$ yang memiliki tindakan yang tidak baik. Sedangkan dari 9 responden yang kurang baik terdapat 8 responden $(88,9 \%)$ yang memiliki tindakan tidak baik, sementara yang memiliki tindakan yang baik dalam efektivitas kepatuhan protokol kesehatan COVID-19 sebanyak 1 responden $(11,1 \%)$.

Hubungan fasilitas terhadap efektivitas kepatuhan protokol kesehatan COVID-19 diperoleh data bahwa terdapat 12 responden $(13,6 \%)$ yang menyatakan fasilitas di Terminal Mallengekeri tersedia dan 76 responden $(86,4 \%)$ yang menyatakan fasilitas di Terminal Mallengkeri tidak tersedia. Sedangkan dari 9 responden yang kurang baik seluruhnya menyatakan bahwa fasilitas di Terminal Mallengkeri tidak tersedia dalam kepatuhan protokol kesehatan COVID-19.

Adapun hubungan motivasi terhadap efektivitas kepatuhan protokol kesehatan COVID-19 diperoleh data bahwa terdapat 85 responden $(96,6 \%)$ yang memiliki motivasi yang tinggi dan 3 responden $(83,4 \%)$ yang memiliki motivasi yang rendah dalam efektivitas kepatuhan protokol kesehatan COVID-19. Sedangkan dari 9 responden yang 
kurang baik dalam efektivitas kepatuhan protokol kesehatan COVID-19, seluruhnya memiliki motivasi yang tinggi.

\section{PEMBAHASAN}

Hubungan Pencapaian Tujuan dan Hasil dengan Efektivitas Kepatuhan terhadap Protokol Kesehatan COVID-19 pada Pekerja Sektor Informal di Kota Makassar

Hasil dalam penelitian ini menunjukkan bahwa terdapat hubungan antara pencapaian tujuan dan hasil dengan efektivitas kepatuhan protokol kesehatan COVID-19 dengan nilai $\mathrm{p}=0.004$. Hal ini diperkuat oleh Edward III (1980) yang menyebutkan bahwa terdapat 4 kritikal faktor yang mempengaruhi keberhasilan implementasi yaitu, komunikasi informasi, sumber daya, disposisi atau perilaku, dan struktur birokrasi (Wahyuni, 2020).

Berdasarkan hasil penelitian di Terminal Mallengkeri, terdapat 54 responden (61.4\%) yang menyatakan pencapaian tujuan dan hasil telah terlaksana dikarenakan responden didukung oleh pemberian informasi dan himbauan terhadap supir terkait protokol kesehatan COVID-19 serta diwajibkannya memakai masker.Selain itu, pencapaian tujuan dan hasil tidak terlaksana namun baik dalam efektivitas kepatuhan protokol kesehatan COVID-19 di Terminal Mallengkeri karena fasilitas cuci tangan sudah tidak terurus dan tidak pernah diisi air. Sehingga, beberapa supir telah baik dalam efektivitas kepatuhan protokol kesehatan COVID-19 dengan membawa hand sanitizer sebagai pengganti cuci tangan dan juga kebanyakan supir angkutan lebih memilih cuci tangan di warung-warung dekat Terminal.

Menurut Karo (2020) pemberian informasi COVID-19 merupakan upaya pencegahan yang dapat sangat berpengaruh terhadap masyarakat dalam pola perilaku masyarakat untuk memutus rantai penularan COVID-19 (Karo, 2020). Hal ini juga sejalan dengan penilitian Rahmadani et al., (2020) yang menyatakan pemberian informasi melalui aplikasi SISRUTE sangat membantu dan memudahkan percepatan pelayanan.

Dalam penelitiannya menunjukkan hasil bahwa penerapan protokol kesehatan pada pelaku UKM akan terlaksana dengan baik jika tersedia sarana dan prasarana yang mendukung. Misalnya disediakan tempat cuci tangan, sabun dan air bersih untuk mencuci tangan atau disediakan masker untuk digunakan selama beraktifitas. Namun, penelitian ini tidak sejalan dengan penelitian Yotlely (2019) yang menyatakan bahwa ketersediaan sarana fasilitas dan informasi tidak mempunyai hubungan yang signifikan dengan kepatuhan. 
Muh. Yusri Abadi, Dian Saputra Marzuki, Suci Rahmadani, Muhammad Al Fajrin, Afiifah, Arvina Pebrianti HR. : Efektivitas Kepatuhan Protokol Kesehatan Covid-19 ...

Hubungan Kepuasan Kelompok Sasaran dengan Efektivitas Kepatuhan terhadap Protokol Kesehatan COVID-19 pada Pekerja Sektor Informal di Kota Makassar

Banyaknya responden yang termasuk dalam katergori tidak puas yaitu 50 responden (56.8\%) dan yang puas 38 responden (43.2\%) dikarenakan mereka beranggapan bahwa memakai masker dan jaga jarak sebagai protokol kesehatan dapat menghambat aktivitasnya saat berada di terminal dan terkadang merasa sesak nafas jika memakai masker terlalu lama, dimana responden tidak nyaman dan belum terbiasa terbiasa. Namun, terdapat pula responden yang merasa takut dan memiliki kesadaran terhadap tertular COVID-19 sehingga tetap menggunakan masker walau merasa tidak nyaman.

Berdasarkan hasil variabel kepuasan kelompok sasaran diperoleh nilai $\mathrm{p}=0.504$, maka tidak terdapat hubungan dengan efektivitas kepatuhan protokol kesehatan COVID19. Hal ini diperkuat oleh teori Philip Kolter (1988) yang menyatakan bahwa Tangibles atau bukti langsung merupakan salah satu faktor yang mempengaruhi kepuasan dimana faktor ini mempengaruhi rasa aman dan nyaman bagi pasien dalam ketersediaan sarana dan fasilitas fisik yang dapat dirasakan langsung oleh konsumen (Supranto, 2004).

Namun, penelitian ini tidak sejalan dengan penelitian Sofyan, Pradhanawati dan Nugraha (2013) yang menunjukkan bahwa fasilitas berpengaruh positif dan signifikan terhadap kepuasan faktor lain yaitu citra merek, harga dan kualitas produk. Jadi fasilitas dapat membuat konsumen menjadi nyaman karena sesuai dengan harapan dan perilakunya (Sofyan, et al., 2013). Hal ini sesuai dengan penelitian Giusman dan Nurwahyuni (2021) yang menyatakan bahwa kepuasan pelanggan mampu meningkat jika didukung dengan teknik menangkap peluang pasar, sehingga rumah sakit mampu memberikan pelayanan kesehatan yang sesuai dengan kebutuhan pelanggan (Giusman dan Nurwahyuni, 2021).

Hubungan Sistem Pemeliharaan dengan Efektivitas Kepatuhan terhadap Protokol Kesehatan COVID-19 pada Pekerja Sektor Informal di Kota Makassar

Berdasarkan hasil dalam penelitian ini menunjukkan bahwa tidak terdapat hubungan antara sistem pemeliharaan dengan efektivitas kepatuhan protokol kesehatan COVID-19 dengan nilai $\mathrm{p}=0.276$. Hal tersebut dibenarkan oleh Notoatmodjo (2003) dalam Anggreni dan Safitri (2020) yang menyatakan bahwa perilaku pemeliharaan kesehatan berdampak pada kepatuhan sehingga dapat merubah perilaku, dari perilaku yang tidak mentaati peraturan ke perilaku yang mentaati peraturan. 
Terdapat 64 responden (72.7\%) pada sistem pemeliharaan yang termasuk dalam kategori baik terhadap efektivitas kepatuhan protokol kesehatan COVID-19 dikarenakan supir dan penumpang memiliki persediaan masker dan hand sanitizer Ketika berada di terminal. Selain itu, Satuan Tugas (SATGAS) COVID-19 selalu melakukan razia protokol kesehatan COVID-19 dengan patroli di area terminal, walaupun tidak melakukan teguran kepada si pelanggar. Namun, pada hasil penelitian yang lain terdapat 24 responden $(27.3 \%)$ yang menyatakan sistem pemeliharaan tidak tersedia namun tetap baik dalam efektivitas kepatuhan protokol kesehatan COVID-19. Hal ini dikarenakan tidak ada pengawasan pada supir dan penumpang dalam mematuhi protokol kesehatan sebab masih kurangnya kesadaran dan ketegasan petugas, selain itu tidak adanya sanksi diberikan kepada responden yang tidak patuh.

Hal tersebut sejalan dengan penelitian Harahap (2016) yang menyatakan bahwa faktor-faktor yang berpengaruh terhadap pencapaian suatu program kesehatan adalah perilaku tidak proaktif untuk memelihara dan meningkatkan kesehatan, mencegah resiko penyakit, serta berpartisipasi aktif dalam gerakan kesehatan masyarakat. Namun, penelitian ini tidak sejalan dengan teori trans-theoretical model Prochaska dan Diclemente (1982) dalam Purwanto and Emilia (2020) yang menyatakan bahwa terdapat lima tahapan untuk dapat mengubah perilaku masyarakat, yaitu prakontemplasi, kontemplasi, persiapan, aksi, dan pemeliharaan.

\section{Hubungan Tindakan dengan Efektivitas Kepatuhan terhadap Protokol Kesehatan COVID-19 pada Pekerja Sektor Informal di Kota Makassar}

Hasil penelitian ini menunjukkan terdapat 37 responden $(42.0 \%)$ yang telah memperoleh tindakan yang baik dan 51 responden (58.0\%) yang memiliki tindakan kurang baik dalam efektivitas kepatuhan protokol kesehatan COVID-19. Hal tersebut disebabkan pengakuan supir angkutan bahwa mereka tidak menjaga jarak ketika berada di Terminal Mallengkeri dikarenakan persepsi responden yang merasa jaga jarak tidak perlu dan tidak adanya sanksi yang memberikan efek jera. Terdapat juga 76 responden (86.4\%) menyatakan bahwa fasilitas Terminal Mallengkeri tidak tersedia dikarenakan anggapan supir angkutan yang menyatakan bahwa tidak adanya sarana simbol/tanda jaga jarak, handsanitizer di tempat-tempat yang jauh dari sarana cuci tangan pakai sabun, dan poster/spanduk/leaflet sebagai informasi tentang edukasi penanganan COVID-19 membuat mereka merasa tidak terpenuhi dari segi dukungan pemanfaatan protokol kesehatan. 
Muh. Yusri Abadi, Dian Saputra Marzuki, Suci Rahmadani, Muhammad Al Fajrin, Afiifah, Arvina Pebrianti HR. : Efektivitas Kepatuhan Protokol Kesehatan Covid-19 ...

Maka dari itu, hasil uji statistik dalam penelitian ini di peroleh 0.085 yang menunjukkan bahwa tidak terdapat hubungan antara tindakan dengan efektivitas kepatuhan protokol kesehatan COVID-19. Hal ini sejalan dengan pendapat Talcott Parsons dalam Kinseng (2017) yang mengatakan bahwa perilaku seseorang (actor) bertindak untuk mencapai suatu tujuan tertentu yang di dukung oleh dua faktor, yakni behavioural organism dan personality, dapat dikatakan sebagai faktor "internal" dari si individu aktor itu sendiri yang mempengaruhi kebijakan atau agensinya.

\section{Hubungan Fasilitas dengan Efektivitas Kepatuhan terhadap Protokol Kesehatan COVID-19 pada Pekerja Sektor Informal di Kota Makassar}

Hasil uji statistik dalam variabel ini menunjukkan bahwa tidak terdapat hubungan antara fasilitas dengan efektivitas kepatuhan protokol kesehatan COVID-19 dengan nilai 0.596. Hal tersebut sesuai dengan anggapan supir yang menyatakan bahwa tidak adanya sarana protokol kesehatan seperti fasilitas cuci tangan, tanda jaga jarak, maupun poster yang membuat mereka merasa tidak terpenuhi dari segi dukungan pemanfaatan protokol kesehatan. Hal ini diperkuat oleh teori Lawrence Green dalam Notoatmodjo (2010) yang mengatakan fasilitas atau sarana dan prasarana merupakan salah satu faktor pemungkin dalam mempengaruhi perilaku atau tindakan seseorang dalam mematuhi sesuatu.

Namun, penelitian yang dilakukan oleh Syamsulastri (2020) tidak sejalan dengan penelitian ini yang mana hasil penelitiannya menyatakan bahwa walaupun dalam penelitiannya tidak ada hubungan, tetapi ketersediaan fasilitas juga dapat mempengaruhi kepatuhan dalam malakukan 6 langkah cuci tangan.

\section{Hubungan Motivasi dengan Efektivitas Kepatuhan terhadap Protokol Kesehatan COVID-19 pada Pekerja Sektor Informal di Kota Makassar}

Motivasi responden terhadap efektivitas kepatuhan protokol kesehatan COVID19 termasuk ke dalam kategori baik, hal ini dikarenakan responden mengakui bahwa mereka memakai masker atas kesadaran mereka sendiri. Hal tersebut dikarenakan supir memilih memakai masker karena terpaksa atau takut terkena sanksi. Adapun hasil penelitian, terdapat 9 responden (100.0\%) yang kurang baik dalam efektivitas kepatuhan protokol kesehatan COVID-19, namun memiliki motivasi yang tinggi. Hal tersebut dikarenakan supir memilih memakai masker karena terpaksa atau takut terkena sanksi. Selain itu, anggapan lain responden juga mengatakan bahwa mereka memakai masker sebagai protokol kesehatan hanya karena ikut-ikutan.

Maka dari itu, hasil uji statistik dalam penelitian ini menunjukkan bahwa tidak terdapat hubungan antara motivasi dengan efektivitas kepatuhan protokol kesehatan 
COVID-19 dengan nilai $\mathrm{p}=1.000$. Penelitian ini sejalan dengan penelitian Dewantara (2018) yang menyatakan bahwa tidak ada hubungan yang signifikan antara motivasi kerja dengan kepatuhan penggunaan alat pelindung diri (APD) di ruang rawat inap Rumah Sakit Paru Jember. hal ini dikarenakan ada faktor-faktor lain diluar motivasi daiantaranya pendidikan, pelatihan, pengetahuan, dan masa kerja yang dapat mempengaruhi kepatuhan (Dewantara, 2018). Namun, hasil penelitian ini tidak sejalan dengan penelitian yang dilakukan oleh Rohmana, Badriah dan Komaruddin (2017) yang menunjukkan bahwa motivasi memiliki pengaruh terhadap kepatuhan masyarakat mengikuti program POMP filariasis. Penelitian ini diperkuat oleh pendapat Kozier (1997), menyatakan bahwa seseorang patuh mengikuti suatu anjuran dipengaruhi oleh adanya motivasi. Dorongan berespon atau berprilaku positif dapat diakibatkan sebagai terhadap kepatuhan (Rohmana, et al., 2017).

\section{SIMPULAN}

Berdasarkan hasil penelitian, ditemukan bahwa hasil uji statistik variabel penelitian menunjukkan bahwa pencapaian tujuan dan hasil $(p=0.004)$, kepuasan kelompok sasaran $(p=0.357)$, sistem pemeliharaan $(p=0.236)$, tindakan $(p=0.068)$, fasilitas $(p=0.288)$, dan motivasi ( $p=0.744)$. Oleh karena itu, dapat disimpulkan bahwa hanya variabel pencapaian tujuan dan hasil yang memiliki hubungan signifikan dengan efektivitas kepatuhan terhadap protokol kesehatan COVID-19 pada pekerja sektor informal di Kota Makassar, sedangkan variabel-variabel lainnya tidak terdapat hubungan. Peneliti menyarankan kepada pihak PD Terminal Makassar Metro setempat untuk melakukan memelihara fasilitas, edukasi, meningkatkan pengawasan serta tegas dalam pemberian sanksi pada pelanggar protokol kesehatan.

\section{UCAPAN TERIMA KASIH}

Terima kasih pada semua pihak yang telah membantu khususnya kepada Dinas Perhubungan Kota Makassar, pihak PD Terminal Makassar Metro, Pekerja sektor informal yang telah berpartisipasi dalam penelitian ini.

\section{DAFTAR PUSTAKA}

Abadi, M. Y. et al. (2019) 'Analisis Kepesertaan Mandiri BPJS Kesehatan di Sektor Informal (Studi di Kota Makassar).pdf', Jurnal Manajemen Kesehatan Yayasan RS. Dr. Soetomo, 05(02), pp. 114-124. Available at: http://files/79/Analisis Kepesertaan Mandiri BPJS Kesehatan di Sektor Informal (Studi di Kota Makassar).pdf. 
Muh. Yusri Abadi, Dian Saputra Marzuki, Suci Rahmadani, Muhammad Al Fajrin, Afiifah, Arvina Pebrianti HR. : Efektivitas Kepatuhan Protokol Kesehatan Covid-19 ...

Anggreni, D. and Safitri, C. A. (2020) 'Hubungan Pengetahuan Remaja tentang COVID-19 dengan Kepatuhan dalam Menerapkan Protokol Kesehatan di Masa New Normal', Hospital Majapahit, 12(2), pp. 134-142.

Dewantara, B. S. (2018) Hubungan motivasi dengan kepatuhan penggunan alat pelindung diri (APD) pada perawat di ruang rawat inap rumah sakit paru jember. Available at: https://repository.unej.ac.id/bitstream/handle/123456789/76414/Bima Satriya Dewantara -1 .pdf?sequence $=1 \&$ isAllowed=y.

Giusman, R. and Nurwahyuni, A. (2021) 'Evaluasi Pelayanan Rawat Jalan RS X Melalui Segmenting, Targeting Positioning Evaluation of Hospital Outpatient Services Through Segmenting, Targeting Positioning Kajian Administrasi Rumah Sakit, Universitas Indonesia Departemen Administrasi Kebijakan', Jurnal Manajemen Kesehatan Yayasan RS.Dr.Soetomo, 7(1), pp. 72-77.

Hanggoro, A. Y. et al. (2020) 'Dampak Psikologis Pandemi COVID-19 pada Petugas Tenaga Kesehatan: A Studi Cross-Sectional di Kota Pontianak', Jurnal Kesehatan Masyarakat Indonesia, 15(2), pp. 13-18.

Harahap, R. A. (2016) 'Pengaruh Faktor Predisposing, Enabling Dan Reinforcing Terhadap Pemberian Imunisasi Hepatitis B Pada Bayi Di Puskesmas Bagan Batu Kecamatan Bagan Sinembah Kabupaten Rokan Hilir', Jurnal Ilmiah Penelitian Kesehatan. Fakultas Kesehatan Masyarakat Universitas Islam Negeri Sumatera Utara, 1(1), pp. 79-103.

Info Penanggulangan COVID-19 (2021) Peta Sebaran COVID-19.

Karo, M. B. (2020) 'Perilaku Hidup Bersih dan Sehat ( PHBS ) Strategi Pencegahan Penyebaran Virus Covid-19', Prosiding Seminar Nasional Hardiknas, 1.

Kemenkes RI (2021) Peta Sebaran COVID-19.

Kemenkes RI. (2020) 'Keputusan Menteri Kesehatan Republik Indonesia Nomor Hk.01.07/Menkes/382/2020 Tentang Protokol Kesehatan Bagi Masyarakat di Tempat dan Fasilitas Umum dalam Rangka Pencegahan dan Pengendalian Corona Virus Disease 2019 (COVID-19)', in Keputusan Menteri Kesehatan Republik Indonesia. Jakarta.

Kinseng, R. A. (2017) 'Strukturgensi : Sebuah teori tindakan', Jurnal Sosiologi Pedesaan, 5(2), pp. 127-137.

Purwanto, E. A. and Emilia, O. (2020) New Normal Sebagai Jalan Tengah?: Kesehatan vs. Ekonomi dan Alternatif Kebijakan Dalam Pandemi COVID19, New Normal: Perubahan Sosial Ekonomi dan Politik Akibat COVID-19.

Rahmadani, S. et al. (2020) 'Implementasi Sistem Rujukan Pasien BPJS Kesehatan Di Puskesmas Pulau Barrang Lompo Makassar', Jurnal Manajemen Kesehatan Yayasan RS.Dr. Soetomo, 6(2), p. 223. doi: 10.29241/jmk.v6i2.459.

Ren, L. et al. (2020) 'Identi fi cation of a novel coronavirus causing severe pneumonia in human : a descriptive study', Chinese Medical Journal, 133(9), pp. 1015-1024. doi: 10.1097/CM9.0000000000000722.

Rohmana, O., Badriah and Komaruddin (2017) 'Analisis Faktor Yang Mempengaruhi Kepatuhan Masyarakat', Media Informasi Poltekkes 
Kemenkes Tasikmalaya, 13(1).

Saputra, H. and Salma, N. (2020) 'Dampak PSBB dan PSBB Transisi di DKI Jakarta dalam Pengendalian COVID-19', Media Kesehatan Masyarakat Indonesia, 16(3), pp. 282-292. doi: 10.30597/mkmi.v16i3.11042.

Satuan Tugas Penanganan COVID-19. Lonjakan Kasus Dampak Abaikan Protokol Kesehatan. Tersedia pada: https://covid19.go.id/regulasi/lonjakankasus-dampak-abaikan-protokol-kesehatan. 2020.

Sofyan, I. L., Pradhanawati, A. and Nugraha, H. S. (2013) 'Pengaruh fasilitas dan kualitas pelayanan terhadap loyalitas, melalui kepuasan konsumen sebagai variabel intervening pada Star Clean Car Wash Semarang', Diponegoro Journal of Social and Politic, 2(2), pp. 1-12.

SulSel Tanggap COVID-19 (2021) Peta Sebaran COVID-19.

Supranto (2004) Statistik teori dan Aplikasi. Jakarta: Erlangga.

Syamsulastri (2020) 'Faktor yang Berhubungan dengan Kepatuhan Perawat Dalam Melakukan 6 Langkah Cuci Tangan', Jurnal Keperawatan Widya Gantari Indonesia, 4(2).

Utami, R. A., Mose, R. E. and Martini, M. (2020) 'Pengetahuan, Sikap dan Keterampilan Masyarakat dalam Pencegahan COVID-19 di DKI Jakarta', Jurnal Kesehatan Holistic, 4(2), pp. 68-77. doi: 10.33377/jkh.v4i2.85.

Wahyuni, T. (2020) 'Efektivitas Peraturan Kepala Daerah Tentang Pening- Katan Disiplin Dan Penegakan Hukum Protokol Kesehatan Di Lingkungan Pemerintah Daerah', Jurnal "Administrasi Publik" Volume, 16(2).

Yotlely, A. S. (2019) Analisis Faktor Yang Berhubungan Dengan Kepatuhan Perawat Dalam Penerapan Kewaspadaan Standar Di Rsud Piru, Universitas Airlangga. Available at: http://repository.unair.ac.id/82988/2/FKP.N. 25-19 Yot a.pdf.

\begin{tabular}{|l|l|}
\hline Submission & $02-06-2021$ \\
\hline Review & $07-08-2021$ \\
\hline Accepted & $19-09-2021$ \\
\hline Publish & $29-10-2021$ \\
\hline DOI & $10.29241 /$ jmk.v7i2.629 \\
\hline Sinta Level & 3 (Tiga) \\
\hline
\end{tabular}

